\title{
Decomposition Rate of Avicennia lanata in Bakau Kecil Mangrove Forest Area, Mempawah District
}

\author{
(Laju Penguraian Serasah Avicennia lanata di Wilayah Hutan Mangrove Bakau Kecil \\ Kabupaten Mempawah)
}

\author{
Asri Mulya Ashari ${ }^{\left.1^{*}\right)}$, Warsidah ${ }^{2}$ \\ ${ }^{1}$ Jurusan Agroteknologi Fakultas Pertanian Universitas Tanjungpura Pontianak \\ ${ }^{2}$ Jurusan Ilmu Kelautan FMIP A Universitas Tanjungpura Pontianak
}

\section{ABSTRACT}

Avicenna lanata is a type of mangrove that dominates the Mempawah Kecil Mangrove Forest. As many as 10 bacterial genera were identified from station 1 which is close to the influence of sea water, and 8 bacterial genera from station 2 which are close to residential areas. This study aims to determine the rate of decomposition of $A$. lanata leaf litter with 4 observation time periods with an interval of 15 days, namely the $15 \mathrm{th}, 30 \mathrm{th}$, 45th and 60th days. The observations show that the rate of decomposition of the litter on the 15 th day of observation is higher. Namely $0.206 \mathrm{gram} /$ day at station I and $0.19 \mathrm{gram} /$ day at station II, while the lowest rate of decomposition of litter occurred on the 60th day of observation, namely 0.112 gram/day at station I and 0.106 gram/day at station II. In addition, the parameters of physical and chemical of the environment such as DO, temperature, $\mathrm{pH}$ and salinity are in the range of their optimum values.

Keywords: decomposition rate, Avicennia lanata, mangroves, litter, optimum.

E-mail: asri.mulyaashari@faperta.untan.ac.id

\section{PENDAHULUAN}

Serasah adalah dedaunan atau tumpukan dari remahan dedaunan dari beraneka ragam vegetasi tanaman yang jatuh ke tanah atau dasar hutan. Warsidah, dkk [1] melaporkan bahwa Avicenna lanata adalah jenis pohon mangrove yang mendominasi hutan mangrove di daerah Bakau Kecil Mempawah. Serasah daun mangrove memilik peran penting dalam siklus kehidupan biota di ekosistem mangrove, menjadi sumber nutrisi bagi organisme atau mikrorganisme agar dapat menjaga kelangsungan hidupnya. Makrozoobenthos merupakan konsumen pertama yang menguraikan daun mangrove dari daun utuh menjadi kepingan atau remahan daun dalam ukuran yang lebih kecil. Yulma dkk [2] menyatakan bahwa remahan atau serasah daun mangrove selanjutnya akan diuraikan oleh keberadaan bakteri pengurai, dengan kemampuannya mempercepat penguraian serasah daun, sehingga mengakibatkan serasah kehilangan bobot yang besar pada masa minggu pertama.

Sejumlah mikroorgansime, bakteri dan jamur berperan utama dalam penguraian serasah daun di ekosistem mangrove. Kathiresan dan Bingham [3] menyatakan bahwa pada umumnya bakteri pengurai serasah daun adalah dari gram negatif. Hanya sekitar $10 \%$ saja bakteri bersifat gram positif dari jumlah total populasi bakteri laut dan sedimen mangrove. Bakteri gram negatif yang berbentuk batang dan mampu melakukan aktivitas gerakan dengan flagella yang mendominasinya, sedangkan bakteri berbentuk kokus keberadaannya lebih sedikit. Penelitian Yahya, dkk [4] menunjukkan bahawa mikroorganisme pengurai serasah daun mangrove paling banyak ditemukan pada perairan dan substrat tanah di ekosistem mangrove.

Ekosistem mangrove yang ada di Desa Sungai Bakau Kecil memiliki luasan sekitar \pm 21,6 ha, sangat potensial dan didominasi oleh jenis Avicennia lanata. Jenis ini umumnya berada di zonasi terdepan pada 
ekosistem mangrove. International Union for Conservation of Nature and Natural Resources (IUCN) menyatakan bahwa $A$. lanata dan beberapa spesies lainnya sebagai salah satu komunitas di hutan mangrove berpotensi rawan punah di masa yang akan datang [5]. Kegiatan budidaya/tambak perikanan, perkebunan dan pemukiman penduduk memegang peran utama dalam kerusakan tersebut. Dalam penelitian Setyawan et al [6] melaporkan bahwa $A$. lanata banyak diburu sebagai bahan baku industri pangan, sedangkan keberadaan komunitasnya dalam ekosistem mangrove antara lain sebagai pelindung pantai, siklus hara dan menjadi tempat perlindungan ikan dan biota ekosistem mangrove lainnya.

Marlangen MSR, dkk [7] dari lokasi yang sama menemukan pada mangrove Avicennia sp. diperoleh sebanyak 42 isolat jamur endofit murni, terdiri dari sebanyak 19 isolat berasal dari daun serasah, dan sebanyak 18 isolat jamur berasal dari daun tua Lanata sp. serta sebanyak 5 isolat berasal dari daun muda Avicennia sp. Warsidah, dkk [1] menemukan bakteri pengurai serasah $A$. lanata di wilayah ini antara lain genus bakteri yaitu Azotobacter, Alcaligenes,
Actinobacillus, Bacillus, Kurthia, Sporosarcina, Listeria, Corynebacterium, Pseudomonas, Serratia, dan Vibrio. Mohammad [8] melaporkan bahwa pada siklus hara, serasah daun akan memberikan kontribusi terbesar bagi kesuburan lingkungan mangrove. Kecepatan dekomposisi dari serasah daun mangrove akan sangat menentukan tingkat kesuburan ekosistem tersebut. Dalam penelitian ini, akan ditentukan besarnya laju penguraian serasah daun $A$ lanata oleh mikroorganise pengurai yang sebelumnya telah diidentifikasi oleh Warsidah, dkk [1], juga kajian tentang parameter fisika kimia lingkungan yang kemungkinan berpengaruh terhadap proses peruraian serasah daun $A$. lanata.

\section{METODE PENELITIAN}

Penelitian dilakukan di bulan Juli - September 2018, berlokasi di Sungai Bakau Kecil, Kabupaten Mempawah, Kalimantan Barat (Gambar 1). Penentuan laju peruraian serasah daun $A$. lanata dilakukan di Laboratorium Jurusan Ilmu Kelautan FMIPA Universitas Tanjungpura, Pontianak.

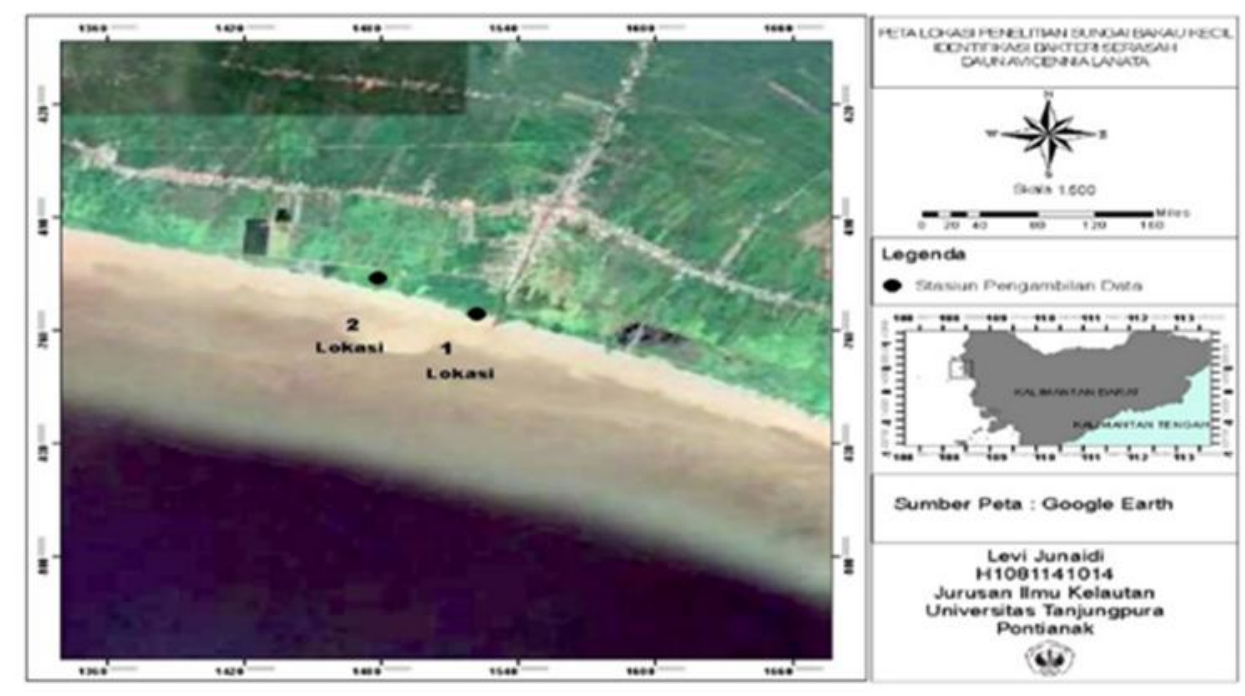

Gambar 1. Peta lokasi penelitian

\section{Peralatan dan Bahan}

Peralatan yang digunakan dalam penelitian antara lain neraca analitik Memmert, Water Quality Checker AZ 8603, peralatan gelas yang umum digunakan, hot plate Faithful SH-2A, litter trap 1 inchi ukuran 1x1 meter, litter bag ukuran $2 \mathrm{~kg}$, mikroskop Binokuler XSZ 107 BN, pinset, sedangkan bahan-bahan yang digunakan antara lain adalah serasah daun $A$. lanata, alkohol 96\% E-merck.

\section{Prosedur Kerja \\ Pengumpulan serasah}

Serasah daun segar dikumpulkan dengan menggunakan metode littertrap (jaring penampung serasah) berukuran $2 \times 2 \mathrm{~m}$ dan diletakan pada setiap 
vegetasi $A$. lanata [9]. Jaring ini ditempatkan pada 2 stasiun pengamatan, di mana setiap stasiun terdapat 6 buah jaring untuk menempatkan serasah daun segar, jadi total terdapat sebanyak 12 buah littertrap penampung. Sampel serasah daun yang terkumpul selanjutnya ditempatkan ke dalam kantong serasah dan disimpan pada permukaan tanah hutan selama 15 hari.

\section{Pengambilan sampel}

Sampel daun serasah $A$. lanata diambil dari kantung serasah dan ditempatkan dalam plastik mika, untuk selanjutnya dibawa ke laboratorium.

\section{Pengukuran laju dekomposisi serasah}

Laju penguraian serasah daun $A$. lanata dihitung dengan menggunakan teknik dan metode yang digunakan [10] yaitu dengan mengambil 3 kantong serasah dalam selang waktu 15 hari, sehingga berjumlah 4 kali pengambilan dalam waktu 60 hari. Selanjutnya dibersihkan dari lumpur dan kotoran lalu dipanaskan dalam oven bersuhu $105^{\circ} \mathrm{C}$ selama 2 x 24 jam, berat kering dihitung dengan timbangan analitik. Persentase laju penguraian dapat menggunakan persamaan Bonruang [11] dan Indriani [12].

$$
\mathrm{Y}=\frac{\mathrm{B}-\mathrm{B}}{\mathrm{B}} \times 100 \%
$$

Keterangan :

$$
\begin{aligned}
& \mathrm{Y}=\text { Persentase yang terurai } \\
& \mathrm{BA}=\text { Berat Awal } \\
& \mathrm{BK}=\text { Berat Akhir }
\end{aligned}
$$

Untuk memperoleh nilai laju penguraian per hari menggunakan persamaan berikut:

$$
\mathrm{X}=\frac{\mathrm{Y}}{\mathrm{V}}
$$

Keterangan :

$\mathrm{X}=$ Nilai laju peruraian serasah perhari

$\mathrm{Y}=$ Persentase serasah yang mengalami peruraian

$\mathrm{BK}=$ Periode waktu pengamatan

\section{Pengukuran parameter lingkungan}

Pengukuran faktor fisika kimia lingkungan hutan mangrove Bakau Kecil dilakukan dengan menggunakan Water Quality Checker AZ 8603.

\section{HASIL DAN PEMBAHASAN}

Kecepatan penguraian serasah daun mangrove menentukan tingkat kesuburan dari ekosistem tersebut. Keterlibatan peran mikroorganisme dari bakteri dan jamur juga menjadi salah satu faktor yang menentukan kecepatan peruraian serasah daun $A$. lanata. Isolat bakteri dari serasah daun mangrove dari penelitian sebelumnya oleh Warsidah [1] memiliki jenis dan jumlah yang beranekaragam, walaupun beberapa di antaranya ada yang mendominasi dalam suatu lingkungan. Beberapa jenis bakteri juga ditemukan pada hampir semua jenis serasah mangrove, seperti Bacillus sp yang juga ditemukan di wilayah yang sama. Tetapi ada juga spesies bakteri yang spesifik hanya ditemukan pada jenis mangrove tertentu saja seperti Nocardiae, Actinobacilus, Staphylococcus, Corynebacterium, Clostridium, Plesiomonas, Pseudomonas, dan Streptococcus.

Bakteri pengurai daun mangrove memegang peran penting dalam siklus daur ulang serasah daun mangrove. Keberadaan mikroorganisme seperti bakteri pengurai tidak hanya mendegradasi unsur utama serasah daun mangrove tetapi dapat mengubah dari hasil degradasi menjadi unsur hara yang siap untuk dimanfaatkan bagi kelangsungan hidup tanaman mangrove lainnya. Unsur Nitrogen, Sulfur, Karbon dan Posfor adalah beberapa unsur hara yang sangat diperlukan untuk pertumbuhan tanaman mangrove [13]. Khanh dkk [14] menyampaikan bahwa bahan organik dari serasah mudah terlarut dalam air pada umumnya memiliki struktur yang sederhana antara lain seperti amilosa, proteoase, glukosa, fenol, dan asam amino. Sementara bahan yang sukar terurai dan sukar larut umumnya terdiri dari lignin, lupeol, selulosa dan xylan.

Laju penguraian serasah dan akan meningkatkan ketersediaan bahan organik di ekosistem mangrove, dapat digunakan dalam pertumbuhan dan perkembangan organisme dalam lingkungan tersebut. Ketersediaan bahan organik pada serasah mangrove dapat mempercepat aktivitas bakteri dalam proses dekomposisi di perairan. Polunin [15] mengatakan bahwa meningkatnya laju peruraian serasah daun mangrove dipengaruhi oleh peran mikroorganisme, seperti jamur dan bakteri, sebagai pengguna dari bahan organik tersebut sebagai substrat untuk sumber energi bakteri. Beberapa kandungan bahan organik dari serasah daun yang dapat dijadikan sebagai substrat mikroorganisme adalah nitrogen dan posfor [16], [17].

Dari pengamatan pada serasah daun $A$. lanata di lokasi penelitian ini menunjukkan bahwa penyusutan bobot dan volume $A$. lanata terjadi dari hari ke $0-60$, seperti ditunjukkan pada Gambar 2. Penyusutan bobot kering serasah daun mangrove $A$. lanata yang terbesar terjadi pada hari ke 15 di lokasi I, yaitu 
penyusutan mencapai 6,9 gram. Penurunan bobot kering serasah daun tertinggi terjadi setelah 15 hari pertama ini karena meningkatnya aktivitas bakteri pengurai serasah daun mangrove $A$. lanata yang ada di dalam kantong serasah [18]. Peningkatan aktivitas bakteri pengurai ini disebabkan oleh tersedianya substrat yang banyak serta keanekaragaman jenis biota mangrove dari serasah daun $A$. lanata.

Pada hari ke 60 bobot berat kering serasah daun pada lokasi I adalah sebesar 3,31 gr dan lokasi II sebesar 3,63 gr, merupakan nilai penyusutan terendah dari serasah daun $A$. lanata. Hari ke 60 mengalamai penyusutan yang sangat kecil disebabkan berkurangnya aktivitas bakteri pengurai dalam menguraikan serasah daun $A$. lanata, seiring dengan berkurangnya jumlah substrat dari serasah daun tersebut yang digunakan oleh bakteri sebagai sumber energi.

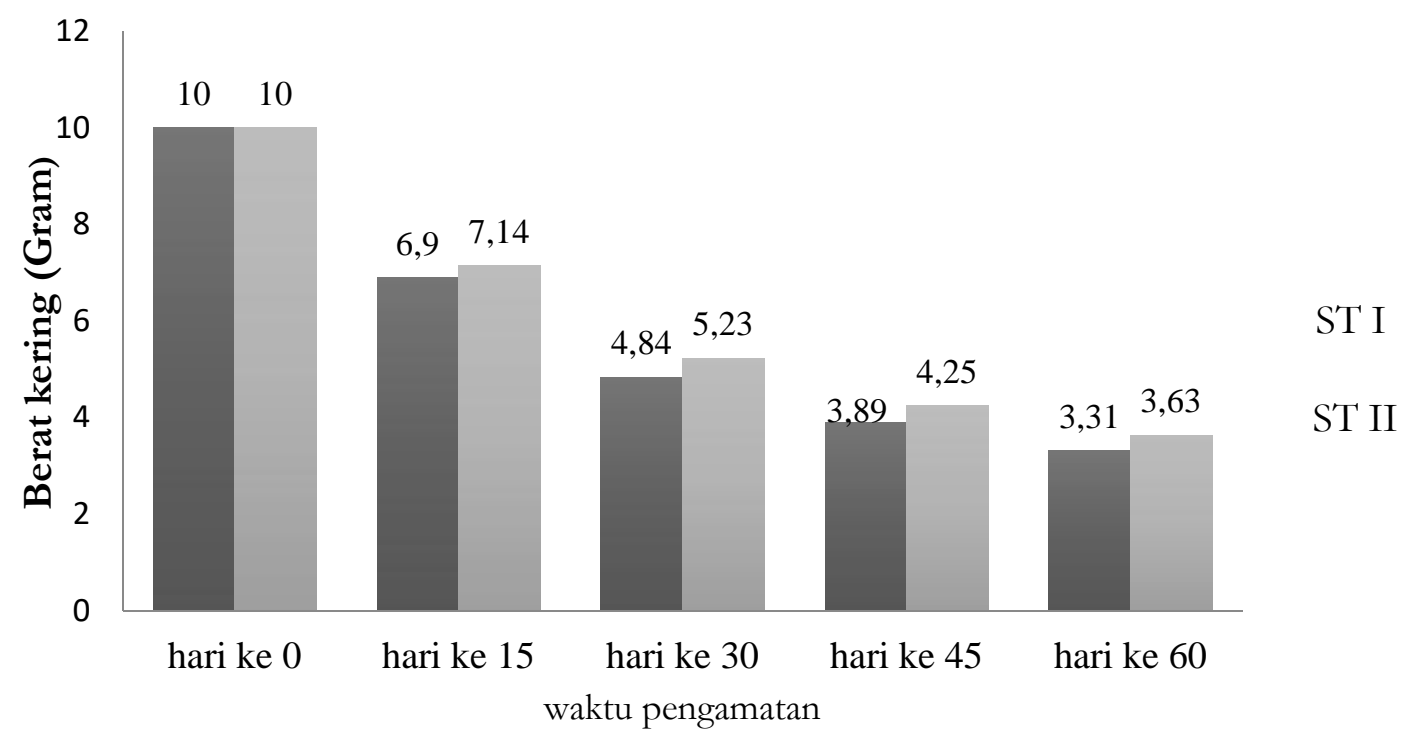

Gambar 2. Grafik penyusutan berat kering serasah daun $A$. lanata
Tingginya laju peruraian serasah mangrove sangat dipengaruhi oleh ketersediaan jenis dan jumlah bahan organik dan mikroorganisme pengurai [19]. Laju peruraian $A$. lanata mengalami penurunan yang besar pada hari ke 60, kemungkinan karena pada masa ini, serasah daun sudah kehilangan banyak komponen organiknya. Seperti yang ditunjukkan dalam penelitian Yulma, dkk [2] dan Lestarina [20]; bahwa menurunnya laju peruraian seiring dengan lamanya periode waktu pengamatan disebabkan oleh semakin sedikitnya bahan organik tersedia, sehingga jumlah mikroorganisme pengurai serasah daun mangrove juga ikut menurun. Beberapa faktor yang juga sangat berperan dalam peruraian serasah daun ini antara lain adalah jenis mangrove dan kondisi parameter perairan atau sedimen di wilayah penelitian [21].

$$
\text { Ket : ST I = Stasiun I, ST II = Stasiun II }
$$

Menurut Yunasfi [22] melambatnya proses perurairan dari serasah daun $A$. lanata disebabkan karena berkurangnya bakteri dekomposer dari daun segar atau yang berada di lingkungan serasah daun mangrove tempat daun jatuh, akibatnya nutrisi yang dibutuhkan oleh bakteri decomposer tersebut tidak dapat tercukupkan dari bahan organik daun mangrove tersebut. Selanjutnya Wahyuni [23] menyatakan bahwa serasah daun mangrove yang kaya nutrien akan lebih cepat mengalami perurairan. Siklus atau proses penguraian serasah daun mangrove selanjutnya menghasilkan nutrien yang akan digunakan kembali oleh tumbuhan serta sebagiannya akan terbawa atau larut dalam perairan di sekitarnya.

Berdasarkan hasil perhitungan, laju peruraian serasah daun $A$. lanata dapata ditentukan seperti ditunjukkan pada tabel berikut. 
Tabel 1. Laju penguraian Serasah daun A. lanata

\begin{tabular}{cccccc}
\hline $\begin{array}{c}\text { Hari } \\
\text { ke- }\end{array}$ & Stasiun & $\begin{array}{c}\text { Dekomposisi } \\
\text { Serasah (gram) }\end{array}$ & $\begin{array}{c}\text { Dekomposisi } \\
\text { Serasah }(\%)\end{array}$ & $\begin{array}{c}\text { Dekomposisi/(gra } \\
\mathrm{m} / \text { hari) }\end{array}$ & $\begin{array}{c}\text { Dekomposisi/ } \\
(\% / \text { hari })\end{array}$ \\
\hline \multirow{2}{*}{15} & Stasiun I & 3,1 & 31 & 0,206 & 2,06 \\
& Stasiun II & 2,86 & 28,6 & 0,19 & 1,90 \\
\multirow{2}{*}{30} & Stasiun I & 5,16 & 51,6 & 0,172 & 1,72 \\
& Stasiun II & 4,77 & 47,7 & 0,159 & 1,59 \\
45 & Stasiun I & 6,11 & 61,1 & 0,136 & 1,36 \\
& Stasiun II & 5,75 & 57,5 & 0,128 & 1,28 \\
60 & Stasiun I & 6,69 & 66,9 & 0,112 & 1,12 \\
& Stasiun II & 6,37 & 63,7 & 0,106 & 1,06 \\
\hline
\end{tabular}

Serasah daun $A$. lanata yang mengalami proses penguraian menunjukkan bahwa bakteri pengurai memiliki kemampuan dalam mempercepat proses dekomposisi [24]. Penurunan bobot kering serasah daun A.lanata pada lokasi I yaitu sebesar 0,112 g selama 60 hari pengamatan dengan nilai persentase bobot serasah yang terdekomposisi adalah $66,9 \%$ atau $1,12 \%$ per hari. Lokasi II mencapai 0,106 g selama 60 hari pengamatan dengan nilai persentase bobot serasah yang terdekomposisi adalah $63,7 \%$ atau $1,06 \%$ per hari. Lokasi I memiliki laju dekomposisi tertinggi pada hari ke 60 yang mencapai 66,9\%. Persentase bobot serasah daun yang terdekomposisi pada setiap lokasi menunjukkan terjadinya perlambatan penurunan dibandingkan hari pengamatan lainnya [25].

Intensitas cahaya matahari adalah salah satu faktor yang berperan dalam ekosistem mangrove. Adanya tutupan kanopi hutan yang luas dapat menghalangi masuknya cahaya matahari, sehingga intensitas cahaya berkurang, seperti ditunjukkan pada Stasiun 1 yang memiliki tutupan kanopi lebih besar indikasi parameter lingkungannya seperti suhu, salinitas, $\mathrm{pH}$ dan Oksigen terlarut (DO) lebih tinggi daripada stasiun II.

Tabel 2. Parameter Lingkungan pada Lokasi I dan Lokasi II

\begin{tabular}{ccccc}
\hline & \multicolumn{3}{c}{ Parameter Fisika dan Kimia Perairan } \\
\cline { 2 - 5 } Stasiun & $\begin{array}{c}\text { Suhu } \\
\left({ }^{\circ} \mathrm{C}\right)\end{array}$ & $\begin{array}{c}\text { Salinitas } \\
(\mathrm{ppt})\end{array}$ & $\mathrm{pH}$ & $\begin{array}{c}\text { Oksigen Terlarut } \\
(\mathrm{mg} / \mathrm{l})\end{array}$ \\
\hline Stasiun I & 32,0 & 12,7 & 6,97 & 3,33 \\
Stasiun II & 30,6 & 10,6 & 7,17 & 3,75 \\
\hline
\end{tabular}

Suhu, salinitas, $\mathrm{pH}$ dan oksigen terlarut mempengaruhi keberadaan bakteri dekomposer serasah daun mangrove $A$. lanata. Menurut Simamora HP, dkk [26] bahwa parameter fisika - kimia seperti $\mathrm{pH}$, suhu, salinitas dan DO tersebut diduga mempengaruhi pertumbuhan dan perkembangan bakteri dan biota mangrove lainnya yang mempengaruhi laju dekomposisi serasah mangrove.

Pada penelitian ini, nilai suhu berkisar antara 30,6 $32,0^{\circ} \mathrm{C}$ dan masih tergolong dalam kisaran suhu optimum untuk biota di ekosistem mangrove yaitu 2832C [27], demikian juga dengan besaran $\mathrm{pH}$ dari hasil pengamatan yang berkisar antara 6.97-7.17 masih dalam range $\mathrm{pH}$ optimum ekosistem mangrove yaitu sebesar 7.0-8.5 [27], salinitas 12.7 - 10.6 permil masih berada pada kondisi optimum salinitas mangrove dengan nilai maksimal 34 permil [27]. Oksigen terlarut (DO) 3,33-3.75 hasil pengukuran menunjukkan nilai yang tidak optimum karena nilainya $<5$, hal ini kemungkinan disebabkan karena pengukuran parameter ini dilakukan pada waktu siang hari, di mana biota mangrove melakukan aktivitas metabolismenya yang membutuhkan oksigen.

Kondisi ini menunjang berlangsungnya proses penguraian dengan menganggap bahwa serasah daun mangrove adalah bahan dasar dalam metabolisme. Suhu lingkungan perairan secara langsung akan mempengaruhi sifat fisiologis mikroorganisme dalam 
lingkungan yang sama, di mana secara langsung akan mempengaruhi aktivitas enzim, sehingga jika suhu meningkat maka aktivitas enzim juga akan semakin meningkat, dengan demikian proses peruraian serasah pun menjadi makin cepat juga [12].

Pengukuran salinitas dalam penelitian ini sebesar 10,6 - $12 \%$ dimana stasiun 2 dengan adanya pengaruh air laut, salinitasnya lebih tinggi daripada stasiun 2 yang dekat dengan pemukiman. Tingginya salinitas di suatu lingkungan akan berdampak terhadap kelimpahan dan keanekaragaman bakteri [28]. Sedangkan menurut Mallin et al., [29] dan Langenheders [30] bahwa meningkatnya derajat salinitas akan menghambat pertumbuhan dan perkembangan koloni bakteri yang berakibat pada menurunnya aktivitas bakteri sehingga memungkinkan terjadinya shock osmotic atau toksis.

Besaran $\mathrm{pH}$ di wilayah pengamatan sebesar 6,97 7,17 masih berada dalam kisaran $\mathrm{pH}$ pertumbuhan yang optimum untuk mikroorganisme yaitu 5,6 - 9,4 $\mathrm{pH}$ optimum adalah kisaran $\mathrm{pH}$ yang masih layak untuk terjadinya aktivitas penguraian serasah daun mangrove. Dalam penelitian Aksornkoae [31] menunjukkan jenis enzim yang paling berperan dalam peruraian serasah mangrove adalah enzim selulase, kerjanya tergantung oleh $\mathrm{pH}$ dan umumnya memiliki $\mathrm{pH}$ yang selektif. Perubahan $\mathrm{pH}$ atau ketidakstabilan $\mathrm{pH}$ akan mempengaruhi terjadinya perubahan tingkat ionisasi dalam aktivitas enzim ataupun substrat dan akan berpengaruh langsung terhadap berlangsungnya proses penguraian dalam ekosistem mangrove.

Pada stasiun pengamatan terdeteksi nilai DO berkisar 3,33 - 3,75 mg/l. Semakin tinggi produksi serasah, semakin tinggi kebutuhan oksigen untuk melangsungkan proses penguraiannya [32]. Kedua stasiun termasuk dalam golongan substrat berlumpur sehingga bahan organiknya melimpah dan akan meningkatkan pemakaian oksigen, sehingga DO menjadi lebih rendah.

Dari penelitian di waktu dan lokasi yang sama telah dilaporkan oleh Warsidah, dkk [1] menunjukkan kelimpahan bakteri pengurai serasah daun $A$. lanata cukup tinggi yaitu 10 genus bakteri di stasiun 1 dan 8 genus bakteri di stasiun 2 .

\section{KESIMPULAN}

Dari hasil penelitian ini dapat disimpulkan bahwa laju peruraian serasah daun $A$. lanata semakin menurun seiring dengan bertambahnya waktu karena semakin berkurangnya senyawa organik dari serasah yang dapat menunjang aktivitas bakteri dekompoeser.

Parameter fisika kimiawi lingkungan seperti DO, suhu, temperatur dan salinitas menunjukkan kisaran nilai yang optimum untuk pertumbuhan bakteri dekomposer serasah.

\section{DAFTAR PUSTAKA}

[1] Warsidah, L. Junaidi, D. I. Prayitno, Identifikasi Bakteri Serasah Daun Avicennia lanata yang Terdekomposisi pada Hutan Mangrove Desa Sungai Bakau Kecil, Jurnal Laut Khatulistiwa, vol. 2, no. 3, pp. 60-65, 2019.

[2] Yulma, B. Ihsan, Sunarti, E. Malasari, N. Wahyuni, Mursyban, Identifikasi Bakteri pada Serasah Daun Mangrove yang Terdekomposisi di Kawasan Konservasi Mangrove dan Bekantan (KKMB) Kota Tarakan, Journal of Tropical Biodiversity and Biotechnology, 2017.

[3] K. Kathiresan, and B. L. Bingham, Biology of Mangrove and Mangrove Ecosystems. Centre of advanced Study in Marine Biology, Annamalai University. Huxley College of Environmental Studies, Western Washington University. Annamalai, India, 2001.

[4] Yahya, H. Nursyam, Y. Risjani, Soemarno, Karakteristik Bakteri di Perairan Mangrove Pesisir Kraton Pasuruan, Indonesian Journal of Marine Science, vol. 19, no. 1, pp. 35-42, 2014.

[5] B. Khairudin, Strategi Kebijakan Pengelolaan Ekosistem Mangrove secara Terpadu dan Berkelanjutan di Kabupaten Pontianak Propinsi Kalimantan Barat, Sekolah Pascasarjana Institut Pertanian Bogor. Prodi Pengelolaan Sumberdaya Pesisir dan Laut. Bogor. (Disertasi), 2016.

[6] D. S. Setyawan, S. Ari, and Sutarno, Biodiversitas Genetik, Spesies dan Ekosistem Mangrove di Jawa Petunjuk Praktikum Biodiversitas: Studi Kasus Mangrove, Universitas Sebelas Maret, Surakarta, 2002

[7] M. S. R. Marlangen, Warsidah, M. S. J. Sofiana, Aktivitas Amilolitik Mikrofungi Endofit Serasah Daun dan Daun Mangrove Avicennia di Desa Sungai Bakau Kabupaten Mempawah, Jurnal LA Aut Khatulisitwa, vol 2, no. 1, 2019.

[8] Mohammad, Estimasi Produksi Ikan Melalui Nutrien Serasah Daun Mangrove di Kawasan Reboisasi Rhizophora, I. Kelautan., vol. 15, pp. 231-235, 2010.

[9] I. R. Simanjuntak, Nursyirwani and Y. Dessy, Production Decomposition Rate and Identification of Bacteria on Avicennia alba Litter in the Coastal Zone Kuala Indragiri Riau Province, pp. 1-13, 2015. 
[10] A. M. Manasheh, Bacterial Decomposition of Avicennia marina Leaf Litter from Al-khor (QatarArabian Gulf). J. Of. Bio. Scien., vol. 8, pp. 717-719, 2001.

[11] P. Bonruang, The Rate of Degradation of Mangrove Leaves Rhizopora apiculata BL and Avicennia marina (Forsk.) Vierh. at Phuket Islan, Western Penisula of Thailand. di dalam : In Soepadmo. Proceeding of the Asian Symposium on Mangrove Environtment Research and Management. University of Malaya and UNESCO., Kuala Lumpur, 1984.

[12] Y. Indriani, Produksi dan Laju Dekomposisi Serasah Daun Mangrove Api-api (Avicennia marina Forssk. Vierh) di Desa Lontar, Kecamatan Kemiri, Kabupaten Tangerang, Provinsi Banten. [Skripsi]. Fakultas Perikanan dan Ilmu Kelautan. Institut Pertanian Bogor, 2008.

[13] W. A. Volk, and F. W. Margaret, Mikrobiologi Dasar Edisi Kelima., Di dalam: Soenartono, A. (ed), Erlangga, Jakarta, 1984.

[14] L. P. Khank, K. T. Huynh, K.T, T.T.K. Nguyen, and T.H.T. Nguyen, Chemical Constituents from Leaves of Avicennia lanata non. Ridley Phamphoang (Avicenniaceae), Sci. and. Tech. Development., vol. 16, pp. 20-25, 2013.

[15] N. V. C. Polunin, Decomposition Processes In Mangrove Ecosystem. Workshop on Mangrove Ecosystem Dynamic. UNDP/UNESCO, 1986.

[16] L. I. Sutiknowati, Kelimpahan Bakteri Fosfat Di Padang Lamun Teluk Banten, Oseanol. Limnol. Indonesia, vol. 36, no. 1 pp. 21-35, 2010.

[17] Sa'ban, M. Ramli, W. Nurgaya, Produksi Dan Laju Dekomposisi Serasah Mangrove Dengan Kelimpahan Plankton Di Perairan Mangrove Teluk Moramo. Jurnal Mina Laut Indonesia. vol. 3, no. 12, pp. 132-146, 2013.

[18] A. Panjaitan, Yunasfi, and S. Tajuddin, Laju Dekomposisi Serasah Daun Rhizophora mucronata dan Kontribusinya Terhadap Nutrisi di Perairan Pantai Serambi Deli Kecamatan Pantai Labu, pp. 1-11, 2014.

[19] R. Pribadi, The Ecology Of Mangrove Vegetation In Bintuni Bay, Irian Jaya, Indonesia. [Tesis]. Scotland: University of Stirling, 1998.

[20] P. Lestarina, Produktifitas Serasah Mangrove Dan Potensi Kontribusi Unsur Hara Di Perairan Mangrove Pulau Panjang Banten. [Tesis]. Sekolah Pascasarjana Institut Pertanian Bogor. Bogor, 2011.

[21] T. Handayani, Laju Dekomposisi Serasah Mangrove Rhizophora mucronata Lamk di Pulau Untung Jawa Kepulauan Seribu Jakarta. [Skripsi]. Institut Pertanian Bogor, Bogor, 2004.

[22] Yunasfi, Dekomposisi Serasah Daun Avicennia marina Oleh Bakteri dan Fungi Pada Berbagai Tingkat
Salinitas. [Disertasi]. Sekolah Pascasarjana Institut Pertanian Bogor. Bogor, 2006.

[23] I. Wahyuni, Jenis-Jenis Bakteri yang Berasosiasi pada Proses Dekomposisi Serasah Daun Avicennia marina (Forsk.) Vierh. setelah Aplikasi Fungi Aspergillus sp., Curvularia sp., Penicillium sp. pada Beberapa Tingkat Salinitas di Desa Sicanang Belawan, Universitas Sumatera Utara, Fakultas Matematika dan Ilmu Pengetahuan Alam, Departemen Biologi, Medan, (Skripsi), 2010.

[24] N. Saibi, and A. R. Tolangara, Dekomposisi serasah Avecennia lanata pada berbagai tingkat kedalaman tanah. Techno: Jurnal Penelitian. vol. 6, no. 1, pp. 55-63, 2017.

[25] Wijiyono, Keanekaragaman Bakteri Serasah Daun Avicennia marina yang Mengalami Dekomposisi pada Berbagai Tingkat Salinitas di Teluk Tapian Nauli, Sekolah Pascasarjana. Program Studi Biologi, Universitas Sumatera Utara. Medan (Tesis), 2009.

[26] H. P. Simamora, Khairijon, M. N. Isda, Analisis Vegetasi Mangrove Di Ekosistem Mangrove Desa Tapian Nauli I Kecamatan Tapian Nauli Kabupaten Tapanuli Tengah Propinsi Sumatera Utara. Jurnal Online Mahasiswa FMIPA UNRI, vol. 1, no. 2, 2014.

[27] Keputusan Menteri Negara Lingkungan Hidup, tentang Baku Mutu Air Laut, 2004.

[28] J. Hrenovic, V. Damir, and S. Bozidar, Influence Of Nutrients And Salinity On Heterotrophic And Coliform Bacteria In The Shallow, Karstic Zrmanja Estuary (Eastern Adriatic Sea). Cevre Dergisi. vol. 46, pp. 29-37, 2003.

[29] M. A. Mallin, K. E. Williams, E. C. Esham, and R. P. Lowe, Effect Of Human Development On Fungical Water Qualitative In Coastal Watershed, Eco Appl, vol. 10, pp. 1047-1056, 2000.

[30] S. Langenheders, Links Bacteria Structure And Fuction Of Heterotrophic Aquatic Bacteria Communities. [Disertasi]. Uppala University. Sweden, 2005.

[31] S. Aksornkoae, Ecology and Management of Mangrove. IUCN, Bangkok, Thailand, 1993.

[32] M. Tis'in, Tipologi Mangrove dan Keterkaitannya Dengan Populasi Gastropoda Littorina neritoides (LINNE, 1758) di Kepulauan Tanakeke, Kabupaten Takalar, Sulawesi Selatan. [Tesis]. Sekolah Pascasarjana Institut Pertanian Bogor. Bogor, 2008. 